\title{
A mulher que matou os peixes, de Clarice Lispector
}

Sandra Regina Kuka Mutarelli UNIP
VAlter Barros Moura UNIP/USP

mulher que matou os peixes infelizmente sou eu", confessa! Um crime sem dolo, sem intenção, quando ela mesma percebe que esquecera de dar-lhes comida. Esqueceu - não de propósito, frisa - porque ela é mulher muito ocupada, escrevendo para adultos e crianças e... com influxos de consciência amalgamados nas palavras, o que torna seus contos complexamente belos e obscuros. Aqui surge uma Clarice Lispector que quebra o próprio paradigma sobre suas obras quando se trata desta obra literária infantil, que se apresenta como a (in)feliz história de uma mulher que por descuido mata dois alevinos de estimação de seus filhos.

Assim brotam relatos, passagens e uma história de compreensão e afeto para com pessoas e bichos. Que fique claro que ela sempre foi alguém que gostou de animais, de crianças e também de gente grande. Todos os bichos que se apresentam em seus livros fizeram, em algum momento, parte de sua vida. Nada mais natural, então, do que contar simplesmente o que aconteceu com cada um deles. Por isto mesmo, estas histórias são narradas de modo coloquial e muito próximo do cotidiano infantil.

Eis uma narrativa sobre dor e perda, quando explica que, às vezes, as coisas acontecem de maneira diferente da que queremos, e é aí que brota uma Clarice que conhece de perto o universo infantil, como quem olha para o universo infantil com uma lupa. Nasce a escritora doce que trata as crianças com a sensibilidade de quem trata as palavras como fios a tecer a delicadeza, agasalha o coração e acalenta o leitor infante e adulto. Só saberemos como tudo aconteceu ao final do livro, pura perversidade lispectoriana. Esta é a mágica que Clarice transporta "maquiavelicamente" do universo adulto para o infantil, porque no início e no meio há várias histórias dos bichinhos que 
teve, como gostou e tratou bem a cada um deles, inclusive os "alevinos vermelhinhos", que eram os dois peixinhos que morreram (de fome, porque ela simplesmente esqueceu de lhes dar comida).

$\mathrm{Na}$ infância há uma gata que havia parido uma ninhada de pequenos felinos que não podiam sair de perto da mãe deles. Quando se desfizeram dos pequenos gatinhos ela nos conta que a saudade da gata e dos seus filhotinhos era tanta, mas tanta, que a deixaram doente. Que o leitor não pense que Clarice só teve por perto "bichos convidados". Absolutamente. Há os não convidados, os "clandestinos" como as baratas e as lagartixas que também moravam clandestinamente em sua casa.

Os ratos podem ser "clandestinos" ou "convidados". Um amigo de Clarice teve uma ratinha "convidada" chamada Maria de Fátima. Clarice agradece a Deus por não ter ratos em sua casa, pois ela tem medo e nojo deles (não sabemos se o medo advém do nojo ou o contrário), até mesmo de Maria de Fátima. Aliás, ela confessa ter pena dos ratos e das baratas: dos ratos, por não serem "um bicho bom para a gente fazer carinho" e das baratas por só serem "amadas por outras baratas" (o que de certa forma sempre lhe causou fascínio). Ela afirma que ninguém gosta de baratas e todos querem matá-las, até ela, que confessa no início da narrativa: "Logo eu! Que não tenho coragem de matar uma coisa viva! Até deixo de matar uma barata ou outra."

Das lagartixas, Clarice fala com carinho. Ela acha as lagartixas engraçadas e são suas amigas já que limpam sua casa comendo moscas e mosquitos. Ela confessa que não tem medo de moscas e mosquitos, mas se sente incomodada com eles.

É importante que o leitor saiba que muitas vezes temos que pagar por um "bicho convidado", é preciso comprá-los! E foi isso o que aconteceu com dois coelhos, depois dois patos, vários pintos, um cachorro que ela teve na Itália e um outro que ela teve nos Estados Unidos. Isso mesmo, Clarice morou em outros países, inclusive na Suíça, e comprou muitos "bichos convidados”. Ela teve também um mico e, algum tempo depois, no seu relato-confissão, foi de um homem que vendia micos na rua que ela comprou a miquinha Lisete.

E teve os dois peixinhos vermelhos "assassinados" por morrerem de fome, por sua culpa. Ela não nos conta apenas sobre os seus bichos, há relatos sobre os bichos de seus amigos, sobre bichos que vivem no mar, como o cavalomarinho, e até sobre periquitos australianos, pássaros e borboletas. Alguns 
dos bichos vivem na ilha de uma amiga e Clarice aproveita para descrever as coisas lindas que tem na ilha - as plantas, as frutas, os cardumes de peixes etc. - e tudo o que podemos fazer numa ilha - tomar banho de mar, nadar, dormir na rede.

Clarice, de forma simples e sucinta, relata características peculiares a cada bicho. De alguns enfatiza as características externas - a feiúra das baratas que viviam em sua casa, a cara esquisita do mosquito que ela observou com uma lente de aumento, o tamanho da lagartixa em relação ao tamanho do jacaré, os botos ou delfins que parecem baleias pequenas, o modo de andar dos patos, o pequeno corpo minúsculo e fofo dos pintos, a semelhança física dos micos e dos homens, o jeito de nadar do cavalo-marinho, a beleza do cavalo etc. De outros ela enfatiza as qualidades inerentes como a amorosidade dos periquitos australianos.

E quanta diferença entre os "bichos convidados" do mesmo tipo, como é o caso dos cachorros: Dilermando, Jack, Bruno, Max e Bolinha. Dilermando é o cachorro que ela teve na Itália, um vira-lata muito inteligente que passava o dia atrás dela para não se sentir sozinho. Jack é o cachorro americano de Clarice, que era um verdadeiro cão de guarda, adorava latir e vigiar a casa. Bruno era o cachorro do Roberto, amigo de Clarice. Bruno era tão fiel e apaixonado por seu dono que não deixava ninguém chegar perto de Roberto, nem para fazer carinho, e acabou matando o cachorro Max por "pura vingança". Bolinha, a cachorra de uma amiga, era uma mãe perfeita para os seus filhotes e era muito sensível e um pouco nervosa.

Mas o leitor se engana se acha que Clarice faz diferenças, pois ela não faz e gosta "de todas as raças humanas e de animais". Para Clarice "o homem é o animal mais importante do mundo, porque, além de sentir, o homem pensa e resolve e fala. Os bichos falam sem palavras". Os cachorros cheiram as coisas para compreendê-las e "são guiados pelo amor do coração dos outros e deles mesmos". "Nós falamos e reclamamos, o cachorro late, o gato mia, todos os animais falam por sons. Mas o peixe é tão mudo como uma árvore" e os peixinhos vermelhos não conseguiram reclamar que estavam com fome.

Clarice conta que existe de tudo neste mundo: mães que têm medo de rato, pais que se divertem caçando ratos ou matando baratas, gente que gosta de cortar a lagartixa com o chinelo e ficar observando o pedaço cortado que continua se mexendo e tremendo. Há mulheres que batem em cachorro, ho- 
mens que ganham dinheiro matando baratas, homens que fazem misturas e inventam perfumes e homens que ganham dinheiro cuidando dos bichos. Há as mães que esquecem a panela no fogo e mães, como Clarice, que são muito ocupadas escrevendo histórias para adultos e crianças. Tem até gente grande que é chata! "Vocês não acham?" Pergunta Clarice, que afirma que "criança nunca é chata".

A autora relata tudo isso para que as crianças se "lembrem quando crescerem que há muito o que fazer na vida". E aconselha que as crianças que gostam de "escrever ou desenhar ou dançar ou cantar" devem fazê-lo, pois "é ótimo: enquanto a gente brinca assim, não se sente mais sozinha, e fica de coração quente". Para ela, a vida é animada quando gostamos do que fazemos. Ela afirma fazer várias coisas na vida e gostar do que faz, mas confessa que muitas coisas ela faz sem gostar, "só por dever". Clarice sente ter matado os peixinhos, pois os peixes não fazem mal para ninguém e "não são ambiciosos: só querem viver". "Pessoas também querem viver, mas felizmente querem também aproveitar a vida para fazer alguma coisa boa”.

Nós perdoamos Clarice. E você?...

\section{Referência Bibliográfica}

LISPECTOR, Clarice. A mulher que matou os peixes. Rio de Janeiro: Rocco, 1999. 